\title{
What We Know Full Well
}

\author{
David Jardine \\ University of Calgary
}

\begin{abstract}
:
This paper affirms that the complex and difficult insights of how teaching, learning and curriculum might shape themselves in light of current ecological alertness and concerns are well known and well documented.
\end{abstract}

Keywords: teaching; learning; curriculum; ecological thinking 


\section{Ce que nous savons très bien}

\section{Résumé :}

Cet article affirme que les connaissances complexes et difficiles de la façon dont l'enseignement, l'apprentissage et le curriculum peuvent se façonner face à l'attention et aux préoccupations écologiques actuelles sont bien connus et bien documentés.

Mots clés : l'enseignement; l'apprentissage; le curriculum; la pensée écologique 


\section{Before the Walk}

$\tau$ am not sure I have much more to say that hasn't been already said over and over again by so
many.

The complex and difficult insights of ecological alertness are known and have been for aeons. The complex and difficult insights of how education might shape itself in light of this alertness has been well documented in recent decades. Witness the papers in this collection and their references lists, full and abundant. Witness how those referred to have their own family trees listed. Follow them, too. Find your way. It's a lush, tough field.

I've witnessed dozens of schools where these matters of teaching and learning and curriculum ecologically imagined are accepted and practiced. I've been a very small part of the tough joys of delicious, good work of teachers and students as they explore deeply interdependent matters, full of relations and abiding and have documented it for decades (e.g., Jardine, 1990, 1996, 2001, and the recent collection, 2016, and a forthcoming book, Latremouille et al., in preparation).

After all, it is not as if curriculum guides don't describe living fields of knowledge, locales, places, terrains wont of attention and affection. The invitation is lying nearby, right on-hand. The theory has become well-wrought and is burgeoning with new stings and insight as we speak. The practices have been well-documented.

But, as per Bill Callahan (2019), "God's face on the water, though plain to see, it's still hard to read" (n.p.).

There is a seemingly perennial return of distraction, fear, panic and exhaustion, and it causes the subsequent fragmentation and scattering of attention in and out of schools, all bent on remedying the situation. But effects of fragmentation and fraught attention are then distraction, fear, panic and exhaustion. The circle closes. The breath stifles.

I forget, all over again, what Raven glances might induce. What they might be asking of me, right here, cupped near the window. No time for such things once we're spooked into this tightcurved enclosure of cause and effect.

All this, too, has been long-since well-known and well-documented. I think of Fredrick Winslow Taylor $(1903,1915)$, the many scholars who wrote about the efficiency movement (see Callahan, 1964; Friesen \& Jardine, 2009; Kanigel, 2005) and the general tearing apart of living fields in favour of sequences and standardized assembly. We teachers know of scripted joylessness and its pretend rigors and the often-low-level anger and sternness and resignation of its applications. We know how such industrial thinking has remained dominant. We know, too, how one feature of a dominant discourse is that it gets to define any alternatives to that discourse. Thus, we know how talk of a walking curriculum, of eco-pedagogical thinking and insight and work, of living fields of knowledge, can of an affection be deemed mushy, silly, childish, subjective, touchy-feely, by the powers that be. And, perhaps most tragic, it is too easy for those pursuing such eco-pedagogical thinking and insight 
and practice to take on the language that the dominant discourse offers us and self-characterize with precisely the caricatures meant to marginalize and silence.

So be it. It is the fate of some to simply suffer these matters in silence, in the resigned belief that this is just the way things are. This sort of ontological codification is a prime weapon of the dominance but, really, just one more of our hegemonic human inventions. It makes the joyous uprising of insight and fervor born of coming upon some strange geometrical relation, or slowly parsing out patterns and materials and timings of nest building over days and days of careful attention, seem like a waste of time.

So much for the preamble. Teachers and students know about all this in the most intimate of ways, of how we've become crowded in and lessened and spent.

This situation has been perpetrated upon us and has been perpetrated by us. Paradox.

It is our fault, to panic and render the world in order to prevent our panic and to then suffer the panic caused by that very rendering over which we then panic.

Humans, eh? We can be such odd ducks sometimes.

But we know something else full well.

We know something is wrong with this ecologically disastrous, ever-accelerating cascade. We know that the surroundings of schooling quickly and easily ignore, marginalize and demean this seemingly secret knowledge we know full well. 


\section{What We Know Full Well}

Tim DeChristopher: We don't know what to do.

Wendell Berry: We do know what to do.

(DeChristopher \& Berry, 2019, n.p.)

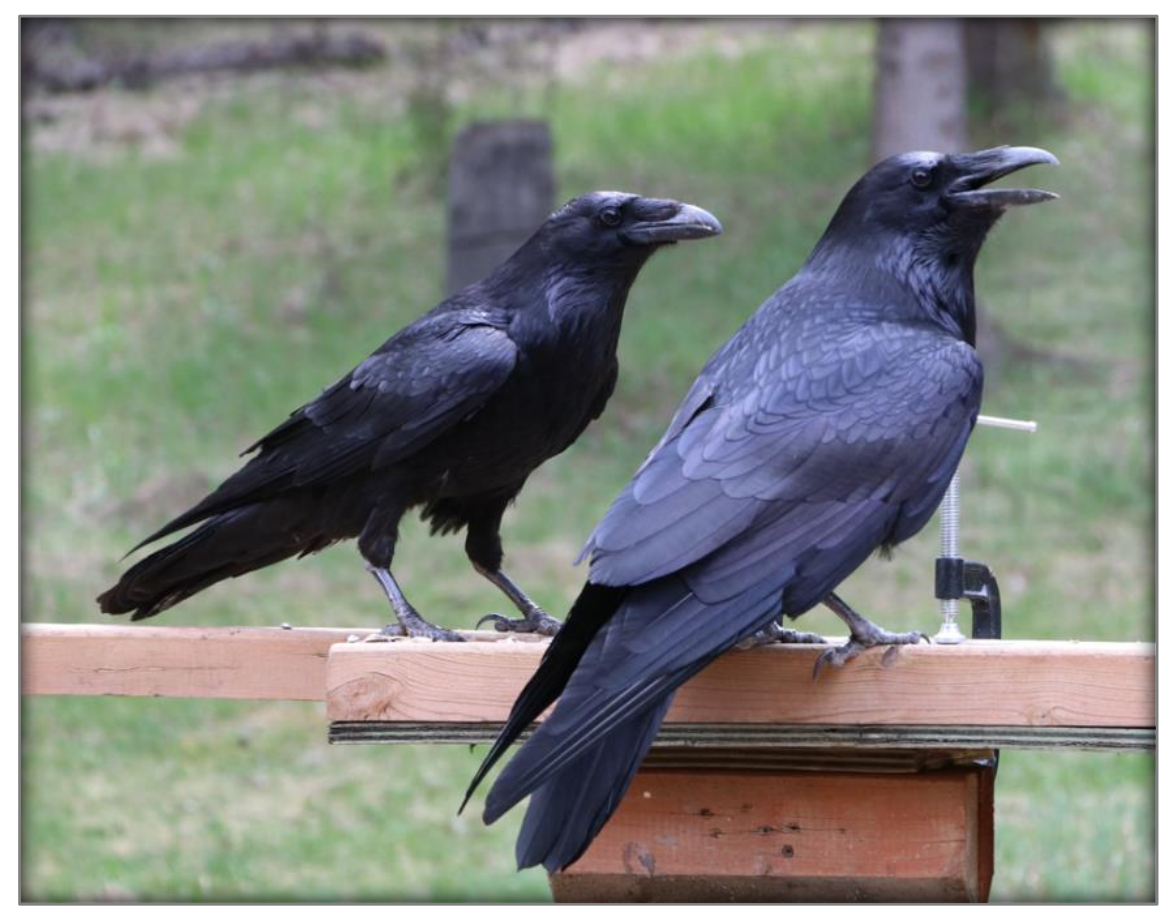

Figure 1. Photo by D. Jardine.

These two raving, steely Raven-lovelies sit here and hereby grant permission for me, for you, to stop a while. Make no mistake, however. This is very difficult to do because our human head-roiling is a tough circus-parade to quell. It must be learned (and then learned all over again). It must be practised (and practised all over again). It must be exemplified, shown to be a respectable, honourable thing, an ancient-and-always-brand-new way to spend one's life learning how to do.

This is why we writers write these things, to give an all-too-meagre permission to do these things.

Our proven-disastrous industrial breakup of ways of knowing is nothing more than a modern bent, useful here and there, but unsustainable when it comes to how the fabrics of knowing, the fabrics of birdways and the geometries of feather overlaps are to be properly understood, the arcswoops of their warm wind air-glides. These are our kin sitting there. Waiting for us. Radiant beings. To know them is to find our common traverse, our mutual strengths, our comfort in each other's sidelong glances.

These matters are not new; they are not strange. They don't call for sloppy emotional subjectivism or poetic overkill. This knowledge of living fields is rigorous and well-read and hard 
work and meticulous. It is an ancient pastime in the face of the brand-new-ness of those Ravens' arrival. Ravens, like old, frail teachers saying "hush, child," (Latremouille, 2014, p. 31; see also Latremouille et al., in preparation) stop your fret, take a breath, look, no, wait, not that. Is it? Check again. Be careful. They'll teach you if you let them and if you let yourself learn how to be taught by them. They'll teach you that, too. Ravens as cause and effect. They patiently showed me again and again. They taught me to go and look and search and see if what I think I see is something seen before.

Yes.

Here it is.

Rictal bristles.

Latin, rictus: "gaping mouth" (Oxford English Dictionary, 2020).

It is hard work to learn how this Latin search is not a turning away but, rather, an intensification of my learning from the Ravens-how it can enrich my attention so that I fill up a feeder again. The traverse of observation and sitting, and the traverse of the words that have graced human ways of naming that traverse of Ravens, are a single gesture.

So, there they are. Ravens. And it is full and clear that they have been nearby thus innumerable times before. So right there in the complex overlapping of those feathers and the astounding precisions of beaks, they bring with them memory trails of persistence and return. Of habits. Of habitats.

Of Rictal bristles.

Of common air. There is that much intimacy with me, the one agape (rictus) at their arrival. They can take my breath away. How much closer can anything be to being worthy of my attention and care? Hale held in common. Common health at stake in their actions and mine. A single gesture.

Seeing them there and realizing something of the complexities of their appearance pulls me up short: well, then, where have I been in the meanwhile? Where have I been with all these goingson going on? And now what? This is what the deep, humiliating pleasure of scholarship feels like, of learning feels like. Schola. Latin. Leisure. But also this: "a holding back, a keeping clear" (Online Etymological Dictionary, n.d., entry under "school"). I recall years ago reassuring student teachers who started to become overwhelmed by the sheer abundance of living relations nested in the simplest of the things they teach. It was like this:

Don't worry. Over on that globe on the shelf are lines called the Tropic of Cancer and the

Tropic of Capricorn. All you need to know is that, when you are able, when you are ready, when you go there, that knowledge and all its relations will be waiting for you.

It is not a matter of gobbling up as fast as possible more and more and more, as if there is some promise, here, of being somehow done. It is a matter of being ready to venture and ready to take good care of what you gather when you do. So, I must then pause and say out loud what is at stake if these Ravens disappear from view, what is at stake if the Earth-housings of knowledge-pine trees, 
bamboo, Ravens, Evening Grosbeaks-become lost.

Perhaps ecological despair is, in part, a despair over the loss of beloved teachers and, thus, a deeper despair over how I must now venture bereft of them, bereaving. Perhaps it is precisely this sense of being abandoned to my own devices (Arendt, 1969) that is the deepest product of the sway of industrial fragmentedness. Solus ipse. Handheld devices. "Device: the "method by which something is divided" (Online Etymological Dictionary, n.d.).

Ravens. The while they stop, and the while we stop over them, is a rare and beautiful thing-as old as dirt and as commonplace and as miraculous, too. This experience and its consorts are openly available. They are not hidden away. But like these Ravens, this experience and its consorts are a bit wary, a bit skittery, easy to scare off under the common duress of schooling.

I know that if you watch this steel-black pair, you'll see them testing nesting sites. You'll see them riding warm-air uprisings in the late afternoons. And the verities of constructs of nests is so veritably abundant, with knowledge ripe and ready to be had, that a lifetime can be spent whiling there, walking about, noting, sketching, reading, writing, listening, speaking, and feeling the warmth and comfort (i.e., common strength) that can come with coming to "know[s] one's way around" (Gadamer, 1989, p. 260). That bristly link between this place's ways and my own footfalls, my own elongated stride of experience. This paradox needs to be embarked full force. A skill housed in the very place that gave rise to it. "We can entrust ourselves to what we are investigating to guide us safely in the quest" (ibid., p. 378). The funny thing about becoming experienced is that

"being experienced" does not consist in the fact that someone already knows everything and knows better than anyone else. Rather, the experienced person ... because of the many experiences [s] he has had and the knowledge [s] he has drawn from them, is particularly well equipped to have new experiences and to learn from them. Experience has its proper

fulfillment, not in definitive knowledge but in the openness to experience that is made possible by experience itself. (ibid., p. 355).

The more often we carefully and considerately walk and tarry, the more those places "become ever richer and more diverse. The volume increases infinitely - and for this reason we learn from [them] how to tarry" (Gadamer, 2001, pp. 76-77) by the practice of tarrying in them. Cause and effect. But this is a loop that slows down as it grows. It slows me down. Who would want to hurry through the rough of rictal bristles? They comfort me and give me evidence that not panicking and accelerating, but rather waiting and watching, can have joyous, rigorous, vigorous yields. Coming to know.

\section{Lingering, Waiting, Walking}

I remember walks on the Bruce Trail with friends where all I ended up seeing was my own feet. Walking always seemed like an intermediary activity meant to get me somewhere else and in a hurry. I didn't properly know how to walk this way. There is something to be said for a walk that pitches up the breath and the pace and the heart and its hot beats. We know about this full well. Heartfelt experience is not just a gooey sentiment, but a recognition of how teased up breath can make the senses tingle in readiness for new experience. 
But then, too, lingering. Old English, circa 1300 lenger, "reside, dwell" (Online Etymological Dictionary, n.d.). Linked to prolonging, lengthening. Linked to "tarrying", first meant as "delaying" (sketching the huffs of my friends sometimes over my malingering on the trail over this or that, slowing their pace) but coming to link to "lingering" by the late 14th century (Online Etymological Dictionary, n.d.).

Tarrying over those Ravens teaches us how to properly tarry over these Ravens. Tarrying is both cause and effect. Paradoxa.

They are teachers, if you let them be, and you can learn from them what sort of attention to them is fitting and proper.

Everything has its beauty, but not everyone sees it. This sets out a pedagogical summons, to learn to see it, to seek out these lessons, to expect these lessons and, if our teachers fail us, to turn away and seek them out for ourselves. It sets out a course of action, a path that must be taken and re-took to be understood. A long traverse of experience is set out, ready, waiting, if you want it. And it speaks in tongues that you must patiently become accustomed to, study, as

the more you practice these things, the more accustomed your mind will become to them, and the easier it will be to practice what you had initially found difficult to learn. You will have visions of the Buddha day and night. (Tsong-kha-pa, 2000, pp. 185-186)

And oh, this oh-so-familiar classroom lament:

Why did he tell us to practice and find out for ourselves? Some people really worry about this.

"If the Buddha really knew," they say, "he would have told us. Why should he keep anything hidden?" This sort of thinking is wrong. We can't see the truth in that way. We must practice, we must cultivate, in order to see. (Chah, 2005, p. 111)

This lament is too often born of long experience in students who find that their classroom conversations end up coming to nothing as the teacher, at the end of those conversations, puts up a list of curriculum bullets that were fully known to be the legitimate outcomes of those conversations long before they occurred and in spite of what might have happened in them.

Pigeon-holes perhaps is a slight towards pigeons.

We must learn to love it when students ask, "Why are we learning this?"

Why do I still sit spellbound by these Ravens every time they arrive and without fail? Because they are beautiful, and they put my anxious life into a more proper measure. They put my own woes into stark-raving relief. They relieve me of myself. Whatever my own exhaustion and despair, warm air rises and right there are volumes of relations out into which my aggrieved heart and breath can expand-weathers, greenhouse heats, growing seasons, reading the weather, maps, fronts. Fields of knowledge as ripe and ready as can be. Waiting. Ravens' unpurposed patience is humiliating of my own rushabouts.

We don't have to learn this, but there is something in its yield. It helps hold back. It helps keep clear. It frees me, if only just for a moment, of the machinations of schools and all its attendant 
panics and frets. And Chogyam Trungpa's (2004) lovely old description of the purpose of such meditations:

Meditation is working with our speed, our restlessness, our constant busyness. Meditation provides space or ground in which restlessness might function. Meditation should reflect a mentality of richness in the sense of using everything that occurs in the state of mind. Thus, if we provide enough room for restlessness so that it might function within the space, then the energy ceases to be restless because it can trust itself fundamentally. Meditation is giving a huge, luscious meadow to a restless cow. The cow might be restless for a while in its huge meadow, but at some stage, because there is so much space, the restlessness becomes irrelevant. (pp. 218-219)

That is the pedagogical promise, that my own restlessness has a chance to become irrelevant. That it can work itself out in the walk about. That's what walks are for, but only if we do them not for that purpose. Paradox.

There. This pair is clustering twigs up unseen in the cup of a 100-foot spruce. I've tried to get a photograph of them swooping with branch-full beaks. Always a bit too late.

Nesting.

Pleasure is to be had in riding such risings of air. Just watch them circle and swoop, wings tight, flight-diving down and resumed with wings flurrying open. And pleasure is to be had in coming to notice it, know it, care for it.

It waits:

We ought to be like elephants in the noontime sun in summer, when they are tormented by heat and thirst and catch sight of a cool lake. They throw themselves into the water with the greatest pleasure and without a moment's hesitation. In just the same way, for the sake of ourselves and others, we should give ourselves joyfully to the practice. (Pelden, 2010, p. 255) And we need to learn about this great, grey, hulking, elephantine trunk-snorffling in our students and in ourselves. We need to learn to love it in ourselves. To love ourselves for it. We know what to do. We know full well how students, with some teasing encouragement, love real work and distain time-wasting, life-wasting days.

This is why we are learning this. To free ourselves from ourselves. Flesh freedom. The deeply human freedom that comes from becoming experienced in the ways of things and the cracking relief of a cold plunge.

What exactly are we waiting for? 


\section{Do Suggest That We've Been Had}

I do understand, and am utterly helpless, sometimes, in the face of the moth-flaming flickering draws.

\section{Really.}

Go ahead, then. Rush off in all directions, as if that is a becoming life, as if I have no choice, as if I just don't understand. This exhausting distraction is the real world.

I suggest that we've been had and need to ask, "Who benefits from my rushing around, my distraction, my exhaustion?" A joke I've told too often, that education professors are too often like heads with the chicken cut off, laying there in the dirt with no body, not running around, but instead, still full of run-on talking, still going "brock bro-brock" as the dust settles and the life slowly drains away, and the bodies run off, and the eyes occlude and film over in air. The other joke that's not quite a joke is telling beginning teachers that first and foremost you stand in front of your students as an example of how human life can turn out. There is always laughter. At first at least. Good. It is funny, but it's not just funny.

Who benefits from me having no time for Ravens, no time to linger over any curriculum topic and cultivate enough of an affectionate, rigorous topographical sense of that living place, that living field of knowledge?

Your and my inability to pay attention to what is happening to us is a deliberate by-product of the world we've inherited:

This world of schooling is not "the real world." It is just how the world has thus far happened to turn out, and the causes and conditions of such turning can be understood, unraveled, and we can unravel ourselves from this turning and, in small, sometimes quite meager and temporary ways, given the largeness of the looming of things, take a breath. (Jardine, 2016, p. xxvi)

Take a breath.

Let your breath be taken by that Raven sighting. "It takes your breath away" is not a metaphor. It is a sign of the arrival of beauty that is known with great fulsomeness in our human history. It is a body function that signals that you've come upon something worthy of your attention, something that, if properly treated, will yield up things secreted away, open fields where my restlessness can become irrelevant all over again. There it is, freely offered.

All that rushing around? It is nothing more or less than the by-product of our human doings that catches us in its spell and depletes us, lessens us. It, too, like the rictus feather of Ravens, can be studied and sorted out, and that sorting out can free us a bit from its strangling. Fredrick Winslow Taylor. The Efficiency Movement. And countless curriculum work that has been marshalled to untangle this rope with which we've unwittingly bound ourselves. This knowledge, this strange little inter-nested habitat of ideas and hopes and despair, is there waiting for you if you want to go for a rather strange walk through something that you already intimately know, something your students 
already intimately know first-hand, day-to-day. Schoolways. References galore! Studied meditations. Classroom examples from real schools in the real world working the grain of things.

All I can manage for now is to fiddle with a magnified gaze-pixilation, for fun, and for the cool lake forward-echoes of our human affection for artful portrayal and also a moment's glimpse of how the mechanics of pixilation is, itself, a strange field of relations, of digital and analogue, of laws and kinds:

It is not merely one's "taking time" to linger over something, as in the slackening or slowing down to contemplate. [It is] ... not a function of lackadaisical, meandering contemplation, least of all passive in any way, but is a function of the fullness and intensity of attention and engrossment (Ross, 2006, p. 109).

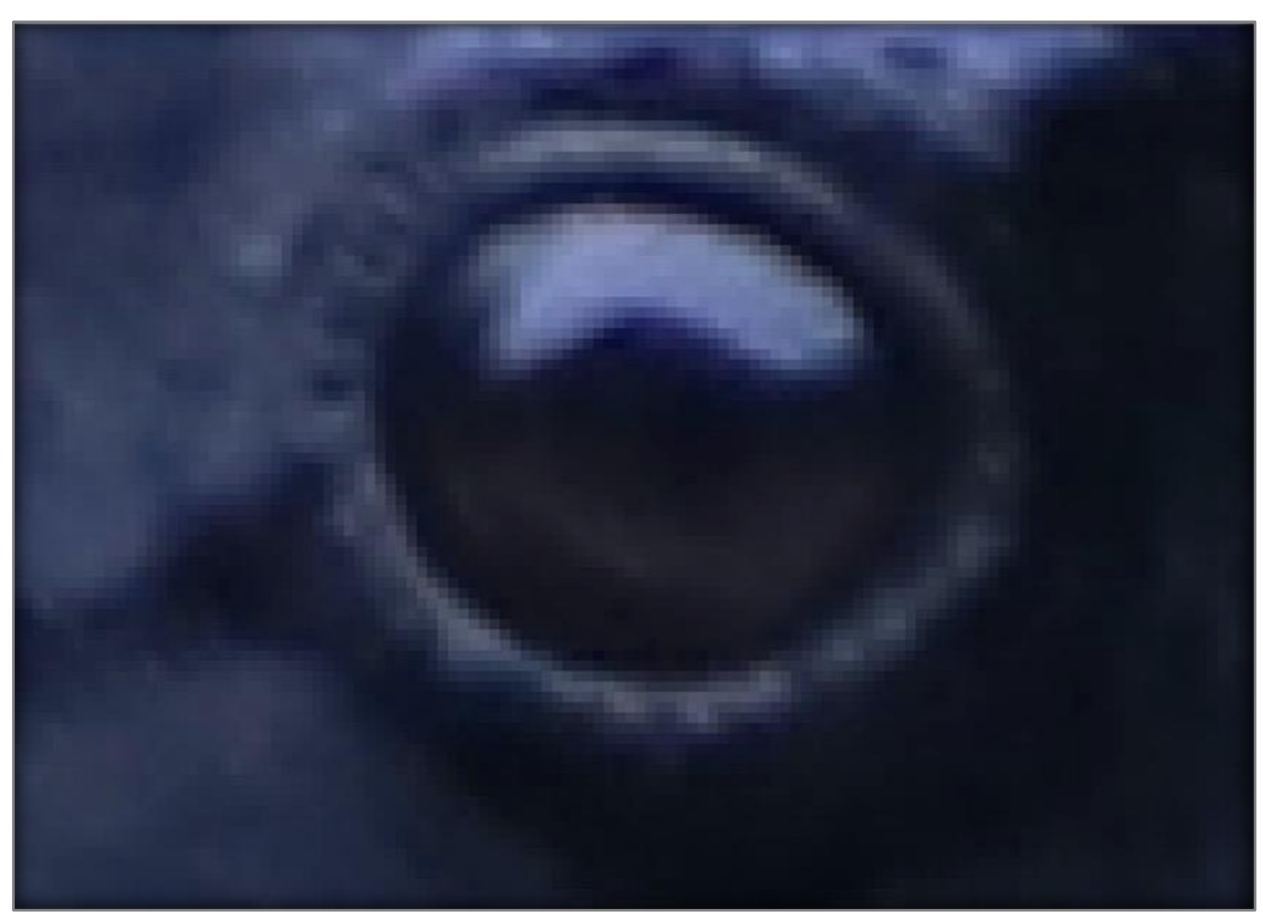

Figure 2. Photo by D. Jardine. 


\section{Sometimes a Side-Trail Becomes The Trail: On Curriculum Guides}

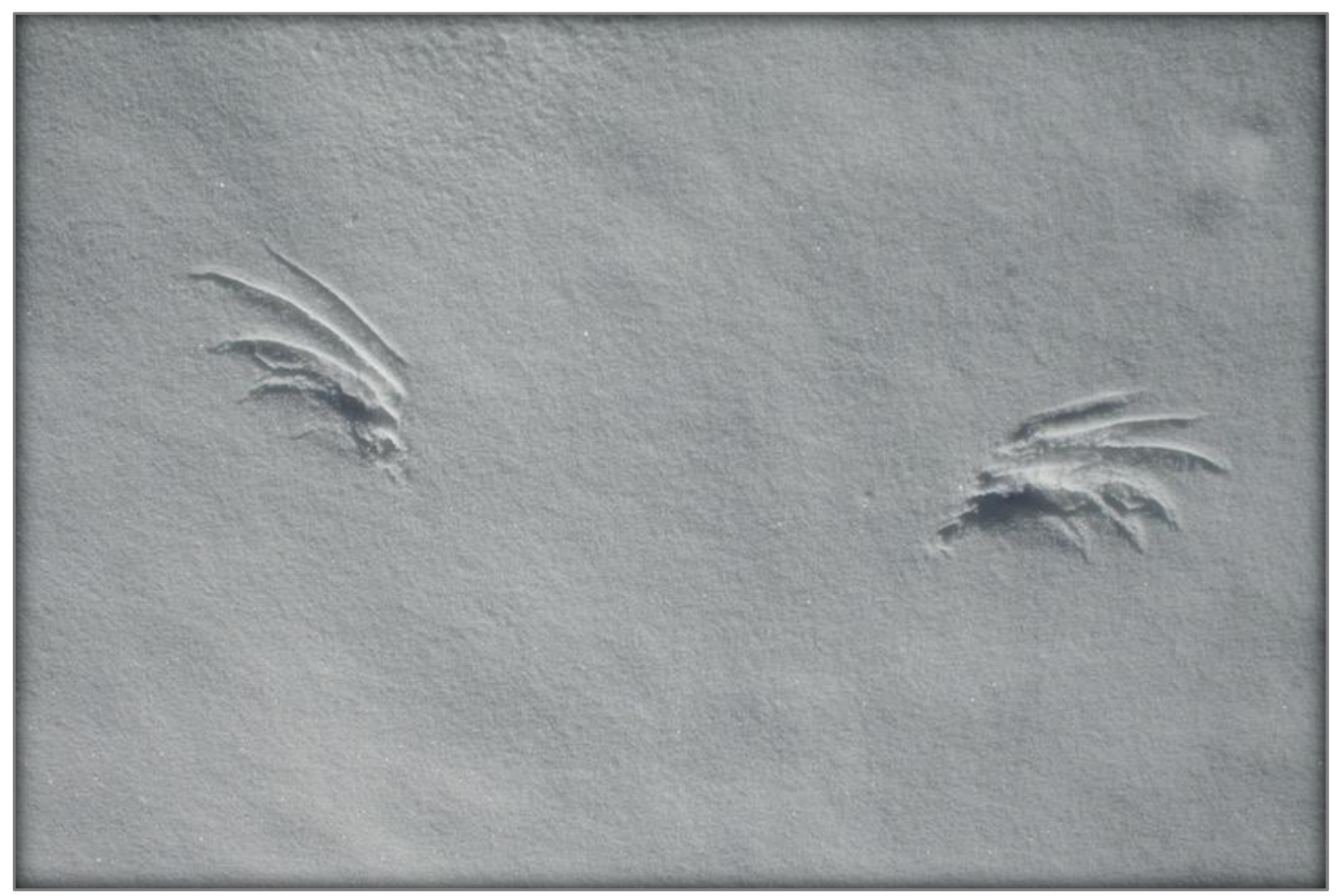

Figure 3. Photo by D. Jardine.

Just a little side-trail. Another Raven picture and some references you can take with you and gnaw on at your leisure. It is good to worry over something worth the chew.

The utter momentariness of wingspreads happening the snow gives glimpse all over again. The art of coming to learn how to experience these matters takes practice. It takes study. For me, it takes the practice of composure, of writing to help up-gather the fleeting passing of wings. Dearer now nearing 70. But even with age, there's nothing new.

"Do not make study and practice into separate things" (Tsong-kha-pa, 2004, p. 221). This is an old snaking falsehood, this separation, an old groaning "theory and practice" debate that simply demonstrates that those theorizing do not understand what theory properly is. It properly is the illuminating of our lives and their family resemblances and the practices we practice, hopefully wisely, well-lit, well-informed, knowledgeably. "Wisdom and the study that it causes are indispensable for proper practice" (Tsong-kha-pa 2004, p. 220). There is no use listening carefully to the elder's tale of snow and wings, or reading a complex tract of the geometries of axis-tilts if it doesn't lead to then noticing that that tale is true in the practice of walking about and learning your way around, of feeling the sun's uprising, Sol's stasis, then descent, a turning, tropos. Why else study if not to increase the roominess of one's steps, one's looking, listening, caressing, remembering.

"You can't get anywhere without [also] reading a yak's load of books" (Tsong-kha-pa, 2004, p. 219). This study is a study on behalf of the practice of composure in the midst of every life. It is a matter of not simply slavishly following the heavy scholarly weight of "tradition" but of, odd 
to say, having "delighted those who have come before" (Dorje, 2011, p. 16) as a way to thus oneself experience delight in this new arising. (Jardine, 2016, p. 175)

Not only is "wherever you are ... a place of practice" (Tsong-kha-pa, 2004, p. 191), Tsong-kha-pa also insists ... the purpose and object of scholarly study is precisely the deepening of practice itself. After all, "why would you determine one thing by means of study and reflection, and then, when you go to practice, practice something else?" (Tsong-kha-pa, 2004, p. 304)

And thus, to loop back to that birding guide: "Texts are instructions for [the] practice" (Tsongkha-pa, 2000, p. 52) of precisely paying more proper attention." Curriculum guides. It is a bad guide that insists on telling you just one more thing so that you don't have to go and see for yourself.

\section{Meanwhile, Speaking of Sorting the Birds and the Bees}

Just this very moment, Monday, June 1, 2020, 9:10 am, Mountain Daylight Time, a female Evening Grosbeak is up on the top of the feeder, and this boy, below, is doing a circular strut on the deck underneath it:

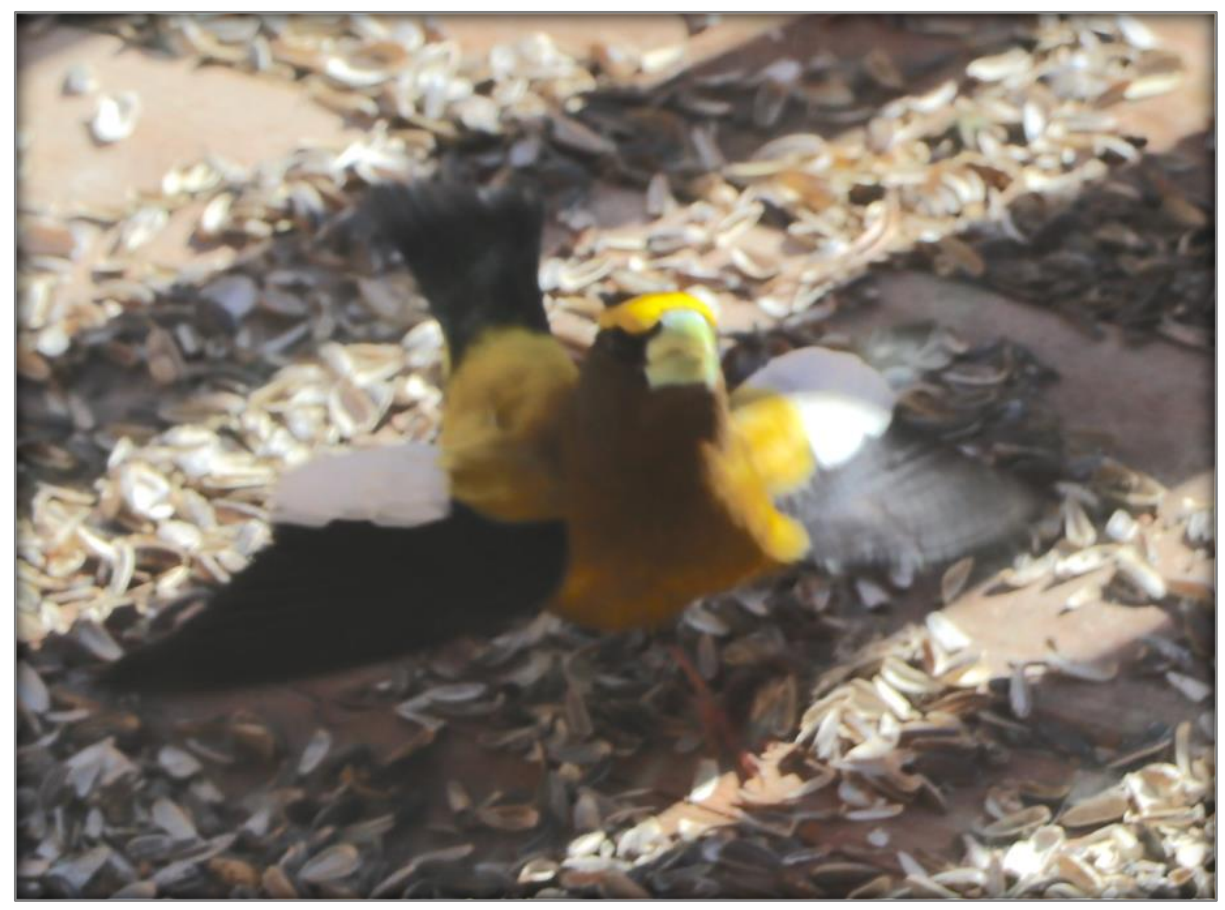

Figure 4. Photo by D. Jardine.

His crooked posture was reminiscent of the posture of a young bird being fed by an elder. Their wings go out, neck bends. The photo below, taken from a few summers back, a common sight, a common kindred spirit, and it is common, too, reasonable, in fact, to seek similarities, family resemblances: 


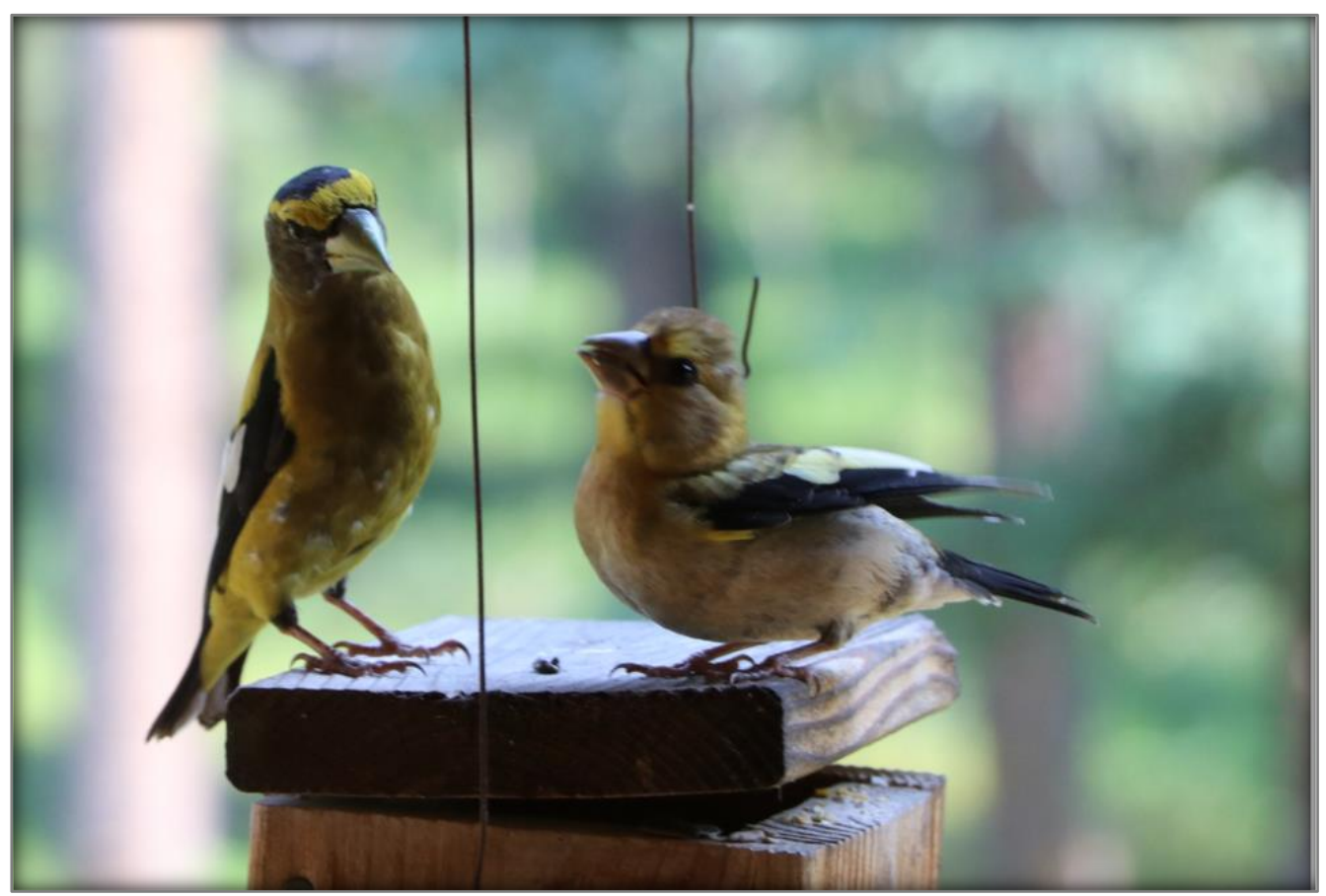

Figure 5. Photo by D. Jardine.

That male's posture on the deck seemed slightly odd and urgent, but also vaguely familiar, a beckoning of some sort or other. Is he a young boy waiting for his mother to come down off the feeder with seed, crooked, waiting, beckoning food, attention? Is that who she is, up there on the feeder? His behaviour seems extreme, maybe, but maybe also akin to last year's feeding picture, perhaps.

But no. Wait. No. Familiar, but unfamiliar. Too extreme, that male deck strutting. Ah, yes, oh. I know this preen. I've seen this male demonstration far beyond the confines of this one species.

The lovely embarrassment of not quite knowing what I'm looking at, and then waiting and venturing and retracting and then finding out. It is not like the elders come to feed the little ones, to help them out, nourish them, take careful care of them.

No.

Down she come to join him, that circle-dancing male on the deck, and, well, oh, yes, of course.

And us humans and our dressed-up circle dances and why we bother doing them in the preens of springtime: 


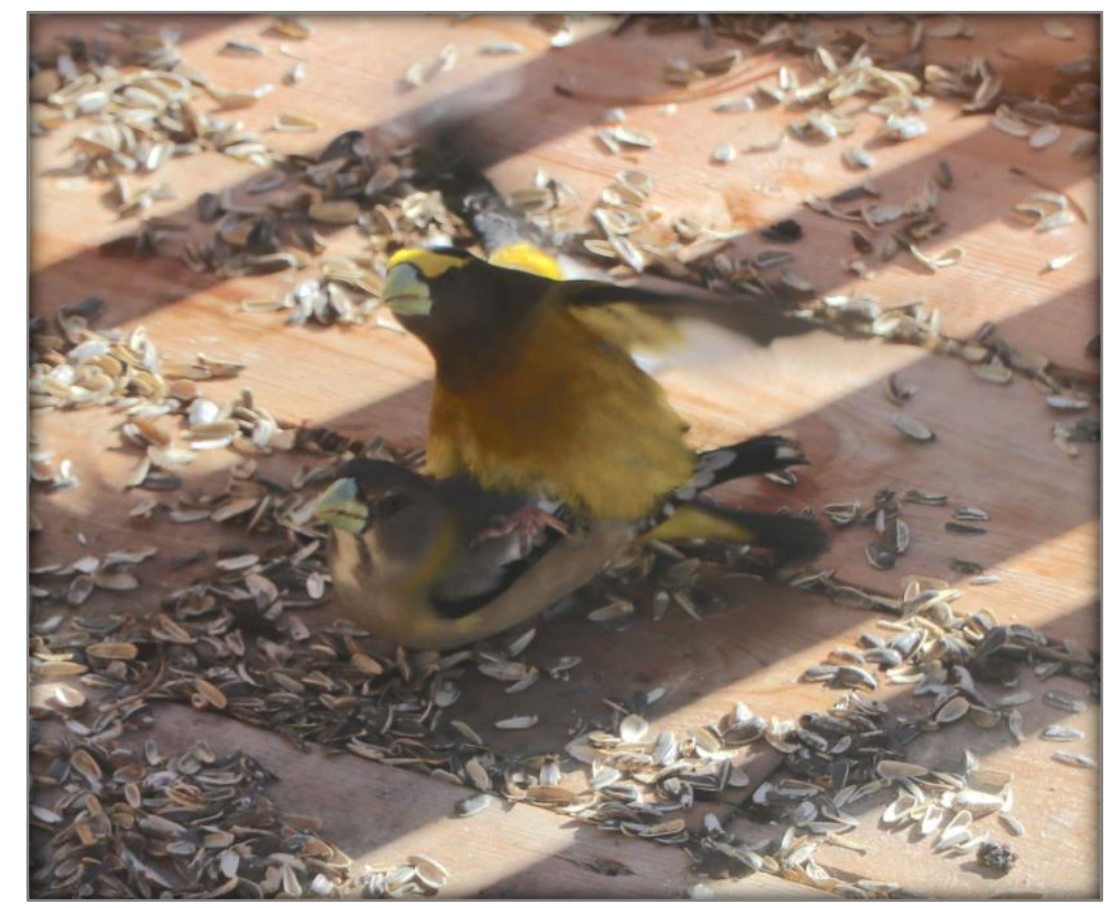

Figure 6. Photo by D. Jardine.

Animals and their habitats, life and its habits. Basic needs. Habitats. Curiosity and shutterclicking something I've never seen before. Questions. Observations. Explorations. Walking. Sitting. Photographing.

Dancing in circles. Writing in circles.

And the ways that the very experience of time itself shifts if you stop looking at your feet rushing down the way.

Just wait.

Time is not running out.

It curls up and nuzzles if you can break the horrid spell and learn to let it. Time running out seems to be the cause of our panic and exhaustion. It isn't. It is caused by our panic and exhaustion which then makes us feel we need to accelerate even further to catch up, thus perpetuating the spell that is killing us. It is killing Ravens and Evening Grosbeaks, too. Shortness of breath should have been a sign all along.

"I can't breathe." This is not just a metaphor for the often-airless corridors of schools and the breathless anticipation of what may be on the test.

The test is here. The test has already happened over and over again. There is no catching up to do. Life and its cycles. Solstice nearing. And the tilts of planetary axes. These birds are astronomical. They seek our affection, our "continuity of attention and devotion" (Berry, 1986, p. 33). Under such 
affection, all their relations will blossom and fly up into the air, taking our hearts with them and flying up all my own relations in their wake:

The water's now well down the driveway in the full mix of things, still-ripple and shining in the mixes of road gravel and horse shit and boot prints in the slush and sloosh. It's why the dogs scurry back and forth when we walk the road. So much dissolved to solve in every whiff. Two great fur saints following the paths of deliquescence. So, there go the Ravens, my dears, again caught and uncaught on the warm Spring-air foothill uplifts. To be dying under their wings is a weird miracle. (Jardine, 2018, p. xiii)

So, okay, let's see, then:

Evening Grosbeaks.

Coccothraustes vespertinus.

Vespers, of the evening. Vespertine.

Night prayers.

Coccothraustes.

kokkos, a seed or kernel.

Thrauō.

To break or shatter.

Deep cousin of trauma and threshing and thresholds

broken through by stepping in.

Daresay of course. Language arts, should you have time for a short walk, a long conversation and a sit.

\section{About the Author}

David William Jardine is a professor emeritus in the Faculty of Education at the University of Calgary. He has an MA from McMaster University and a PhD from the University of Toronto.

\section{References}

Arendt, H. (1969). Between past and future. Penguin.

Berry, W. (1986). The unsettling of America: Essays in culture and agriculture. Sierra Club.

Callahan, B. (2019). What comes after certainty [Song]. On Shepherd in a Sheepskin Vest. Drag City

Records. https://www.dragcity.com/products/shepherd-in-a-sheepskin-vest

Callahan, R. (1964). America, education and the cult of efficiency. University of Chicago Press

Chah, A. (2005). Everything arises, everything falls away. Shambala.

DeChristopher, T., \& Berry, W. (2020, March 2). To live and love with a dying world. Orion Magazine. https://orionmagazine.org/article/to-live-and-love-with-a-dying-world/

Dorje, L. (2011). A torch lighting the way to freedom. Shambala.

Friesen, S., \& Jardine, D. (2009). On field(ing) knowledge. In S. Goodchild \& B. Sriraman (Eds.), Relatively and philosophically e[a]rnest: Festschrifte in honour of Paul Ernest's 65th Birthday (pp. 149-175). Information Age. 
Gadamer, H.-G. (1989). Truth and method (J. Weinsheimer \& D. G. Marshall, Trans.). Continuum. Gadamer, H.-G. (2001). Gadamer in conversation: Reflections and commentary (R. Palmer, Ed. \& Trans.). Yale University Press.

Jardine, D. (1990). "To dwell with a boundless heart": On the integrated curriculum and the recovery of the Earth. Journal of Curriculum and Supervision, 5(2), 107-119.

Jardine, D. (1996). "Under the tough old stars": Pedagogical hyperactivity and the mood of environmental education. Canadian Journal of Environmental Education, 1(Spring 1996), 48-55. Jardine, D. (2001). "All beings are your ancestors": A bear Sutra on ecology, Buddhism and pedagogy. Talking Leaves: A Journal of Our Evolving Ecological Culture, 11(2), Summer/Fall 2001, 38-39.

Jardine, D. (2016). In praise of radiant beings: A retrospective path through education, Buddhism and ecology. Information Age.

Jardine, D. (2018). Preface: Advice in this liquid midst. In E. Lyle (Ed.), The negotiated self: Employing reflexive inquiry to explore teacher identity (pp. vii-xiv). Brill/Sense.

Latremouille, J. (2014). Feasting on whispers: Life writing towards a pedagogy of kinship. [Unpublished master's thesis]. University of Calgary.

Latremouille, J., Tait, L., \& Jardine, D. (in preparation). An ecological pedagogy of joy: On relations, aliveness and love.

Moules, N. J., \& Estefan, A. (2018). Editorial: Watching my mother die-Subjectivity and the other side of dementia. Journal of Applied Hermeneutics, Editorial 3, 1-3. https://doi.org/10.11575/ jah.v0i0.57328

Online Etymological Dictionary (n.d.). Device. In Online Etymological Dictionary. Accessed September 14, 2020 from https://www.etymonline.com/search?q=device

Online Etymological Dictionary (n.d.). Linger. In Online Etymological Dictionary. Accessed September 14, 2020 from https://www.etymonline.com/search?q=lingering

Online Etymological Dictionary (n.d.). School. In Online Etymological Dictionary. Accessed September 14, 2020 from https://www.etymonline.com/search?q=school

Oxford English Dictionary. (2020, July). Rictus. In the Oxford English Dictionary. https://www.oed.com/view/Entry/165617?redirectedFrom=rictus

Pelden, K. (2010). The nectar of Manjushri's speech: A detailed commentary on Shantideva's Way of the Boddhisattva (Padmakara Translation Group, Trans.). Shambala.

Peterson, R. T. (1980). A field guide to the birds east of the Rockies (4th ed.). Houghton Mifflin.

Piaget, J. (1965). Insights and illusions of philosophy (W. Mays, Trans.). Meridian.

Ross, S. (2006). The temporality of tarrying in Gadamer. Theory, Culture \& Society, 23(1), 101-123.

Trungpa, C. (2004). The collected works of Chögyam Trungpa, Volume 3: Cutting through spiritual materialism. (C. Gimian, Ed.) Shambhala.

Tsong-Kha-Pa. (2000). The great treatise on the stages of the path to enlightenment [Lam rim chen mo]. (Vol. 1; The Lamrim Chenmo Translation Committee, Trans.). Snow Lion.

Tsong-Kha-Pa. (2004). The great treatise on the stages of the path to enlightenment [Lam rim chen mo]. (Vol. 2; The Lamrim Chenmo Translation Committee, Trans.). Snow Lion. 